\title{
Challenges and Sustainability of China's Socio-Economic Stability in the Context of Its Demographic Development
}

\author{
Andrea Čajková ${ }^{1}$ [D and Peter Čajka ${ }^{2, *}$ \\ 1 Department of Public Administration, Faculty of Social Sciences, University of Ss. Cyril and Methodius, \\ 91701 Trnava, Slovakia; andrea.cajkova@ucm.sk \\ 2 Department of International Relations and Diplomacy, College of International and Public Relations Prague, \\ 15000 Praha, Czech Republic \\ * Correspondence: cajka@vsmvv.cz
}

Citation: Čajková, A.; Čajka, P. Challenges and Sustainability of China's Socio-Economic Stability in the Context of Its Demographic Development. Societies 2021, 11, 22. https://doi.org/10.3390/soc11010022

Academic Editor: Elzbieta Antczak

Received: 14 February 2021

Accepted: 4 March 2021

Published: 16 March 2021

Publisher's Note: MDPI stays neutral with regard to jurisdictional claims in published maps and institutional affiliations.

Copyright: (c) 2021 by the authors. Licensee MDPI, Basel, Switzerland. This article is an open access article distributed under the terms and conditions of the Creative Commons Attribution (CC BY) license (https:// creativecommons.org/licenses/by/ $4.0 /)$.

\begin{abstract}
Like many developed countries in the world, China currently faces many serious demographic challenges that pose a potential risk to the country's socio-economic development and stability. The current demographic development and trend is characterized by a change in the reproductive behavior of the population, characterized by a decline in birth rates, a change in family behavior, and a shift in the value system. This paper is aimed at identifying the impact of population policy and the degree of its influence on both the economic and social system of the country. Based on a deterministic approach, the findings reveal and demonstrate the serious demographic challenges facing China, and we are noting that there is no guarantee that parametric adjustments, such as shifting the retirement age, will de facto ensure the financial health of the pension system by preventing bankruptcy. We point out the risks and prospects for the sustainability of China's socio-economic development based on an analysis of past and current Chinese demographic policy.
\end{abstract}

Keywords: China; socio-economic development; demographic development; population policy support; pension reforms

\section{Introduction}

The population cannot be considered a static element; on the contrary, it is characterized by strong dynamics of its number, structure, spatial distribution, and other features [1-3]. At the same time, changes in individual traits are usually chain-linked and are a characteristic and very important process of each population [4-6]. The actual dynamics of the population involve a large number of processes, which are differentiated at different geographical levels and with which there are also special problems [7]. Population growth is related to ensuring its very physical existence, in many regions especially to the problem of providing basic living needs [8-11], at the same time to emerging issues related to sustainability of other societal domains such as climate change, demographic pressures and global sustainability, food waste, and the need to develop policy strategies for its optimization [12-14]. At a lower level, issues such as securing the required number of jobs, increasing national income, shaping the social structure, etc., come up with population dynamics. From a demographic point of view, China is currently facing two trends in the context of historical development: firstly, life expectancy in China has improved significantly over the last few decades and moved closer to developed countries $[7,15,16]$, and secondly, China's fertility rate has changed even more dramatically [17-19]. China is a country with a working population that has grown the fastest in the world in recent decades. It will now turn into a country with a shrinking population the fastest in the world. Increasing the share of the post-productive population is thus beginning to put strong pressure on the social and pension system.

The article presents an overview study of the causal links between social, economic, political, and cultural forces and demographic processes examined through a demographic 
perspective. Our aim is to point out how the complete and immediate homogenization of reproductive behavior would change in the future, the results of projection, and the number of demographic events and changes. This paper contributes to research examining the effects of the implementation of strategic and planning documents and policies, and this information is considered the basis for development, especially from the point of view of socioeconomic evaluation resulting from the principle of sustainable development. Our effort was through qualitative analysis of data of the monitored aspects carried out in the context of pointing out the links between population and economic growth that refers to the problems of pension and social security both in China and in comparison with the situation in Europe. Our research intention is thus mainly focused on the context of the sustainability of China's socio-economic development in the area of the pension system based on an analysis of the consequences of past and current Chinese demographic policy.

\section{Literature Review}

China has benefited from a period of demographic dividends during the first three decades of its market economy reform since the late 1970s. The country's overall dependency ratio continued to decline from 1970 to 2010 [1]. It now appears that the period of demographic dividends is over. China faces the serious issue of an aging population. According to forecasts by the UN Population Division, the ratio of young and older dependents to the total population in China will increase to about $50 \%$ by the middle of the century, when the number of working-age adults will be roughly equal to the number of dependents in the country [2]. The statutory minimum productive age of 16 is legal in China under the Labor Act [20]; people under the age of 16 are counted as young dependents. People aged 60 and over are counted as older dependents, taking into account the current average retirement age of around 57 [21] and the likely shift in the retirement age in the following decades. These two population groups are expected to account for $14.1 \%$ and $34.6 \%$ of the total population in 2050 [2], leading to a ratio of $48.7 \%$ of young and older dependents to the total population.

Problems in China's social security system can be found in two key events: the disintegration of the state economy, which provided urban workers with an "iron rice bowl" (employment, housing, health care, and pensions), and the introduction of a onechild policy in the 1980s, which meant that their parents could no longer rely on a large family to take care of them in old age $[22,23]$. In other words, with the development and liberalization of the economy in the 1980s and 1990s, state and social structures that supported workers in their old age, poor health and economic hardship gradually disappeared, leaving a huge vacuum [24].

The impact of the population aging on pension sustainability in China, as well as understanding the complexity of the pension system and its reform, has been extensively discussed in the past few decades in the literature. In recent years, the issue of demographic development in China has been very much discussed in professional discussions in connection with further economic developments in the country and their impact on the stability and reform of pensions. The debate on reforming the retirement age is very lively, which could have a major impact and address the current effects of the global economic and financial crisis on the Chinese economy. Issues of current population development, population aging, as well as pensions can be found, for example, in the works $[3,21,25-33]$.

In this context, various problems of pension reform in China have also been identified and analyzed in various aspects of the pension system, such as its coverage, adequacy, fairness, and method of financing. However, the institutional feature of the Chinese pension system, which is highly fragmented and decentralized, and its potential impact on pension sustainability have not received sufficient attention in the current literature. The issues of pension provision, the problems and complexity of the pension system, as well as the reform process have been processed, especially in the last two decades, by a number of domestic and foreign researchers [34-53]. The availability of officially published data in the field of demographic development and forecasts, as well as on the management 
and financing of pensions and pensions is relatively limited and very often ambiguous, as official government statistics very often contradict official data such as UN databases or statistical data from the environment of independent organizations. For this reason too, some of the conclusions presented may be the result of the availability of various baseline data.

The issue of demographic, pension, and pension provision of the society also has an immediate impact on issues of the current and future position of the Chinese economy in the global economy. Since the Chinese government began to implement its decision to reform and open the country in the late 1970s, China has undergone a major transformation supported by more than three decades of stable and rapid growth. The economy recorded an average annual growth rate of gross domestic product (GDP) of $9.8 \%$ during the first 35 years of the ongoing transition from a command economy to a market economy, even during the last economic crisis. However, the growth momentum of China has appeared to be tapering off in recent years in the aftermath of the 2008 global financial crisis. In 1989, GDP growth averaged $9.4 \%$, reaching its highest level of growth of $15.4 \%$ in the first quarter of 1993. As a result, China has become the world's second largest economy and largest trading country $[52,53]$ and has become an increasingly important driver of growth for many other countries [54,55]. Thus, China's prospects for future development depend not only on the benefits of its 1.4 billion people, but also have a major impact on maintaining regional and global economic prosperity.

However, under the pressure of China's trade war with the US and long-standing structural problems such as declining demand abroad, declining foreign investment, and rising labor costs, recorded annual GDP growth in 2019 was 6.1\%, 990,865 bln. CNY, the slowest growth rate in 30 years. The timing of the epidemic and the looming wave of unemployment (unofficial estimates of $20 \%$ ) came in 2020, the year that was meant to end poverty and double economic growth since 2010. In the first quarter of 2020, year on year China's GDP fell by $6.8 \%$, with negative economic performance for the first time in 44 years. The reason was disrupted supplier-customer relations and declining demand abroad. The main drivers of the Chinese economy in the first quarter of 2020 year-on-year were domestic consumption $(-19 \%)$, exports $(-11.4 \%)$, and investment in fixed assets $(-16.1 \%)$. In 2020, for the first time since 1985, the government did not set an annual GDP target with reference to unpredictable global economic developments. The development of the economy can also be affected by the impending geopolitical isolation of the country. China is beginning to have a tendency to isolate, focusing in particular on the internal market and strengthening its position in the Association of Southeast Asian Nations (ASEAN) region. In the first quarter of 2020, ASEAN countries became China's most important trading partner (instead of the EU) [56].

At present, we can observe that similar demographic developments and pension and social security problems are faced by most developed countries in the world. In fact, all European countries, not recognizing the European Union(EU) countries, have been facing unfavourable demographic developments in recent years, which have resulted in a natural demographic decline. This is not the result of the implementation of a managed population policy, as in the case of China, but the process of natural social development in the developed countries of the world. Like China, these countries are currently suffering from the dynamics of post-productive population growth and the subsequent aging of the population, which requires a reassessment of the current economic, social, and pension settings of individual economies [7].

\section{Materials and Methods}

The research methodology was based on critical qualitative content analysis of the qualitative data and literature from the various data bases and information sources: EBSCO Information Services (Elton B. Stephens Company), Google Scholar, Web of Science (WoS), Scopus, as well as data from National Bureau of Statistics of China and international organizations as the United Nations (UN), The World Bank, The Organisation for 
Economic Co-operation and Development (OECD), etc. This enabled the generation of a rich discussion of the issues from the perspective of China. The methodological approach was based on interdisciplinary and multi-paradigm approach, taking into account the publications from areas of demography (fertility, aging, and urban/rural population) and economy (pension and social system). Demographic processes and outcomes are seen as among the best measures to understand human societies and changes. Implemented retrospective analysis and identified trends in the field of demographic development represent exceptional information entering prognostic models. It is not possible to predict the future without understanding past trends. The analyses of the monitored aspects are carried out in the context of forecasting the problems of pension and social security both in China and in comparison with the situation in Europe.

We used a deterministic approach, which defined the set of national population development within the assumed scenarios. The parameters used in the model were taken from official sources, such as UN databases and the World Bank. As part of the Fertility Index analysis, we work with World Bank data, where the initial year is 1965, so for the period 1965-2018, we use a retrospective approach and for the period 2020-2100 in the area of Development of the Chinese population prospectus. We used the UN projection from 2019. The results should always be considered as rough estimates. Most importantly, the period at the end of the first decade of the new millennium is characterized by a very low level of fertility as a result of the one-child policy and at the same time as a current trend in the population development of the developed countries. This state is a proper threshold for the purpose of the simulation. We represent virtual boundaries of convergence and divergence, so we do not have to use a probabilistic approach with certain confidence intervals. Several other studies have addressed this task. Our study can be considered as complementary. Relative simplicity is offset by comprehensibility and pronunciation for a wider audience, while probabilistic methods sometimes suffer from the complexity of projection users.

\section{Results}

An example of a country where population policy has significantly influenced both the country's economic and social system for many decades is currently China. Today's population policy, aimed at controlling the population of the People's Republic of China, affects approximately 1.4 billion Chinese. This policy also includes other restrictions in the form of national migration and gender policies. Among other things, it has an impact on other areas of life in the country, including education, health care, and other social spheres. Its population development from the second half of the 20th century represents a unique "experiment" in the application of political decisions and tools to the functioning of society as a whole.

However, the consequences of such a policy can be largely politically distorted by the decision of political elites to knowingly or unknowingly modify the facts. Such a case may be conscious misinformation informing about the total Chinese population. Yi Fuxian [57], for example, concluded in his book Big Country with an Empty Nest that Chinese population statistics have been based on false and exaggerated data since 2000 and that the actual size of the Chinese population may be 100 million smaller than what the National Statistical Office states. Yi and colleagues found that UNFPA (United Nations Population Fund) predictions for the Chinese population were based on markedly inaccurate data that cause the deviation of tens of millions of people. This may be due to the fact that both Chinese and UNFPA officials have been for years using to measure Chinese birth statistics and to predict the future Chinese population trajectory incorrect total birth rate data varying from 1.6 to 1.8. The fact is that the National Statistical Office found in both censuses from 2000 and 2010 that the total birth rate was around 1.22, more precisely 1.18. This adjustment means that millions of new-borns are "added" to Chinese birth statistics every year. As a result, the size of the Chinese population has increased 
by tens of millions. It can be said that China is the only country in the world with such extremely inaccurate population statistics [57].

China's population development, especially since the second half of the 20th century, has been marked by significant differences between the urban and rural environments and between individual ethnic groups. In the case of China, it is worth noting that this is a country with a history of several thousand years, a country which has belonged several times in the history of mankind to the power and cultural centres of the world, as well as to its declining peripheries, boasting a level of education in recent decades, although it has faced relatively high illiteracy of its population. It is a country whose population we still do not know, not only in the Middle Ages but also in modern times. Demographers' estimates vary widely and often fail to justify significant fluctuations in the projected development of the Chinese population. It is certain that from the 18th century to the present, the Chinese

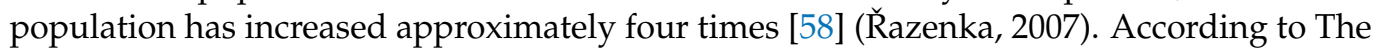
World Factbook, approximately $18 \%$ of the world's population currently lives in China (1.394 billion-July 2020) [4], whereas according to the United Nations, it is 1.439 billion [5].

The current population development of Chinese society is in addition significantly influenced by the application of the political principle of the so-called one child policy [59]. The so-called one-child program was introduced in 1979 by Mao Tse-tung. However, it should be noted that China is not the only country where population policy is implemented. The one-child policy introduced by government circles is unique in some respects, as it has not been applied in this form in any other country. Although its aim was to secure the future of the country's population, its opponents consider the biggest negative to be that it violates universally recognized human rights, such as the right to free choice, the right to human dignity, and the right to personal protection against unauthorized interference with private life. The first country in the world to decide to address population growth was India in 1952 with the introduction of a family planning program. India pursued an antinatal policy during the 1970s in an effort to limit the population explosion but did not exacerbate it to the form we can see in China. Since the 1990s, the Indian government has gradually begun to abandon this policy. Another example is Kenya, which opted for such a program in the late 1960s. Other constraints that should lead to a reduction in the birth rate in the population are being encountered in countries such as Bangladesh and Indonesia, where there is a population explosion [10]. By order of the Central Committee of the Communist Party of China of 25 September 1980, the one child policy regulation entered into force. The aim of this policy was to raise China's standard of living as well as the country's social and economic development. However, the first attempts to intervene in the development of the population began almost twenty years earlier, i.e., in the late 1950s.

After the end of the Second World War, China became one of the countries of the so-called socialist bloc. Since 1949, the Chinese Communist Party, led by leader Mao Tsetung, has held a privileged position in the country's leadership. We consider his opinion on the criticism of the Minister of Foreign Affairs of the United States of America, Dean Acheson, to be one of the first opinions on the state of the Chinese population. He publicly expressed doubts that China would be able to feed its population in the future. Mao Tse-tung responded by saying that a large population is good for China, because human life is the most valuable gift, and if there are people in the country led by the Communist Party, any miracle can happen. We can define this reaction as pronatalistic. Nevertheless, already during this period, the Chinese leadership was clearly aware of the negative effects resulting from the extreme population growth. Gradually, they came to the need to manage this population development in a targeted manner [9].

One of the most important stimuli that forced the government to decide to deliberately manage the development of the Chinese population was the statistical forecast of Chinese experts. Dr. Ma Yinchu [60] from the University of Beijing was one of the first to point out a possible population explosion. In 1957, he published an article entitled "A New Population Theory," in which he proposed a reduction in overcrowding and a method of ensuring appropriate population growth in the country. When the Chinese government came up 
with a "one couple, one child and, in the worst case, two" population policy in the 1970s, about a million planning professionals went to work and visited the families and talked to them about the family and distributed contraception for free.

Other studies have predicted, e.g., [61-64], that if the extreme growth of China's population is not halted, it will overpopulate at the turn of the millennium. The studies stated that a standard family with three children would increase China's population to 1.4 billion in 2000. By the middle of the 21st century, the Chinese population would have reached the level of 2.92 billion individuals. Another assumption, with a family of two children, predicted that China's population would grow to 1.22 billion in 2000 and increase to 1.54 billion by 2050. During this period, the population would also reach its maximum. Subsequently, the population would decline and stabilize at 1.47 billion. These high numbers posed a frightening threat to the government. It therefore decided to take a swift and uncompromising step in the form of a population policy known as the "one-child policy", which was supported by a massive campaign [65].

The first legal measures related to limiting the growth of the population in China can be traced back to the Marriage Act of 1980 and the Constitution of the People's Republic of China, which was adopted in 1998. Although population policy in the People's Republic of China was announced in 1979, regular legislation did not occur until 2001, when a legal regulation known as the Act on Population and Family Planning was adopted (Population and Family Planning Law of the People's Republic of China) [15] (p. 297).

The Marriage Act, which entered into force nationwide on 1 January 1981, is a kind of basic legal regulation that regulated not only the conclusion of a marriage itself, but also family relationships. Article 6 in II. Chapter of the Act states that the required minimum age for marriage is 22 years for men and 20 years for women. However, the law itself recommends that marriages be concluded at a later age and that the couple should wait with procreation. Couples considering marriage must follow several steps. First of all, they must register with the marriage registration office. If they do not register, they cannot obtain the marriage certificate required to be allowed to have a child. Despite this obligation, customary law marriages are still held in western and less developed areas of China today. However, these marriages are considered invalid by law. At the same time, children who come out of such a union are considered illegal and are outlawed [15].

Elements based on the one-child policy can also be found in other laws, e.g., People's Republic of China Law for the Protection of Women's Rights and Interests, adopted in 1992, or People's Republic of China Law on Health Care for Pregnant Women and Infants 1994 [66,67]. Under the adopted Law of the People's Republic of China on health care for pregnant women and infants, health care in the country should create such conditions as to ensure the best possible care for mothers and newborns. The law also includes mandatory premarital examinations, the aim of which is to determine whether individuals are able to conceive a child, or whether there are any serious diseases in the family that could affect the offspring [16]. The People's Republic of China Law on Population and Family Life was adopted in 2001, 22 years after the official announcement of population policy. The introductory article of the law states that this regulation was approved in accordance with the Constitution of the state, as a tool to achieve coordinated development of the population and at the same time the economy, society, conservation of natural resources, and the environment. Article II states that family planning becomes an official policy of the People's Republic of China and at the same time allows the government and its authorities to use all available means to control the size of the population [16].

According to many, the official one-child policy runs counter to the international legal system dealing with the rights of the child, which the Chinese government itself has committed itself to upholding. In 2006, the People's Republic of China Law on the Protection of Minors was adopted [68]. As part of the content of this law, the country is committed to supervising and protecting children and their personal development. The law also regulates the responsibility of the family and grants children the right to education, health care, or judicial protection. However, these rights do not apply to so-called illegal 
children. These are descendants who were born without a "permit", i.e., outside the marriage allowed by the authorities.

\subsection{Population Policy Support}

In order for the top officials of China to achieve a positive effect of official population policy, they created a system of various campaigns. It was a massive propaganda campaign that we can encounter several times in the history of the country. An example is the Great Cultural Revolution, during which government officials tried to instil in the population the basic idea of a policy that was to lead to its successful application in practice. The primary goal of promoting the one-child policy was to provide a kind of enlightenment among the population, which would lead them to adhere to the established policy. This propaganda was especially challenging in rural areas, where starting a large Chinese family was common [69].

Even before the official introduction of the one-child policy, the first two campaigns aimed at population growth in the country were carried out in 1957 and 1962. The campaign that began in 1957 aimed to recommend the use of contraceptives in order to limit the number of children born in one family. Today, this government policy can be interpreted as proof of the need to intervene in population development. Another campaign in 1962 was focused on introducing new types of contraception. At the same time, it tried to persuade the people of China to enter into marriage at an older age. Today, we can say that no campaign had a significant impact on the growth of the state's population. The biggest problem was to change the mindset of people who were influenced by the habit of starting traditional families with a high number of children. The problem of extreme population growth escalated especially in rural areas, where poor people identified their wealth with a large number of children. Along with this tendency, sexual issues in these areas of the country were still a great taboo. Although the campaigns were not successful, there was still a slight reduction in population growth. This happened during the introduction of the so-called the "big step forward", when there was a famine in the country between 1958 and 1960, during which an estimated 20 to 30 million people died. Nevertheless, the government remained concerned about population growth [9].

The basic tools used by the authorities of the People's Republic of China to promote population policy were various posters, slogans, and newspaper, television, and radio advertisements. We can say that people have been confronted with this policy on a daily basis at every turn. The groups targeted by this propaganda were the young generation, married couples, and expectant mothers and fathers. At the time of the introduction of the policy, China was still a technically underdeveloped country, and therefore the most effective form of propaganda was slogans and posters that could be placed anywhere. It was the posters, thanks to their visual elements, that were able to attract people's attention. Simple and concise slogans clearly conveyed basic information about state policy. The great advantage of posters and slogans is that they do not require such significant financial costs compared to other propaganda tools [16].

A whole complex of "rewards and repressions" was created to support one-child families. Families with one child have a better chance of solving the housing situation, better access to health services, and higher contribution to the salary. Women and mothers are in this case entitled to paid "maternity leave". The state does not contribute to the second child at all, and in the case of the birth of a third child, the family must already pay for the "offense". Severe sanctions have been imposed in China for violating the one-child policy regulation. Parents who resist get fired, their houses are destroyed, their tractors are confiscated, or they are being sent to prison.

The state has been strictly monitoring and regulating population policy since the 1980s, and if a Chinese family decides to have another child without "state permission", the state has often ordered such women abortion. In 1983, approximately 10 million induced abortions were performed there, of which almost 90\% were forced. Between 1975 and 1995, more than 200 million conceived children were killed in China [70] (p. 15). 
Girls were particularly discriminated against in this regard. Chinese society and more precisely Chinese families have historically and traditionally preferred male descendants. If even the first child is born as a girl, the parents get permission to give birth to another child.

Chinese families in remote rural areas, where they value sons more than daughters, have been offered a financial reward by the authorities to stop women who are expecting a girl from having abortions to help reverse gender imbalances. Under the name Care of Girls, the authorities have launched a pilot program in which girls are exempt from school fees, families with daughters have insurance paid by the state until they grow up, and those who have only one girl can benefit from various benefits in housing, employment, education, and other privileges. The National Commission on Population and Family Planning has called for a friendlier environment for girls and for gender imbalances to be rectified.

In 2005, the Chinese government even began paying annual incentives of about $\$ 150$ to parents raising daughters. Statistics show that there are only 100 girls per 119 boys born. In one Chinese province, there is even a village where the ratio of a second-born child is 100 girls to 250 boys [63]. The result of such a development may be the fact that in 2020 there will be 30-40 million more men than women living in China, which may have dangerous social consequences for the whole society.

As a result of population policy, more than 90 million children have been growing up in China since the 1980s who will probably never have a sibling. At present, the fertility of Chinese women has fallen to one of the last places in the world, despite the fact that more than $60 \%$ of Chinese would like to have two children.

At the end of the 1980s, a two-child model of the family ("from below") began to be promoted [11]. At the end of the 1990s in the population of large cities, we can observe trends in the level of birth and fertility typical of economically and socially developed countries. Residents of the towns were able to "buy" a permit to have a second child. In Shanghai, such a fee amounted to approximately $€ 4000$, which was three times the average annual income in the city [71].

Major problems and unrest in connection with the one-child policy took place in 2007 in the south of China in Guangxi Province. The poor and agricultural south has significant problems in complying with the strict population rules of one child. Farmers thus often break the law, whether for economic or family reasons. According to available information, for violations of the Number of Children Act, inspectors levy fines of \$65-9000, even retroactively back to 1980, and require these fees even if the family has paid for the second child in the past. Families who refuse to pay the fee are often confiscated property and are detained by the police [72].

Chinese population policy also had its response in the traditional understanding of the "Chinese family". The traditional understanding of the family "beginning of marriage and early childbirth", "the more sons, the more happiness", and "men are superior to women" was gradually replaced by a planned family with a change of view of the family "later marriage and later childbirth" and "boys and girls are equal". This principle significantly affected the status of marriage, when, e.g., the first marriage was concluded in 1998 by women of reproductive age averaging 23.57 years, while in 1970, it was 20.8 years. In connection with the introduction of the one-child policy, e.g., increased contraceptive use among women of childbearing age to $83 \%$, while significantly reducing the average size of family members from 4.84 members in 1971 to 3.63 members in 1998, significant population changes that Chinese society has undergone have also responded in the degree of urbanization of the country (see Table 1).

Table 1. Urban population in the China as a percentage of the total population, 1950 to 2050.

\begin{tabular}{lccccccccccc}
\hline & $\mathbf{1 9 5 0}$ & $\mathbf{1 9 6 0}$ & $\mathbf{1 9 7 0}$ & $\mathbf{1 9 8 0}$ & $\mathbf{1 9 9 0}$ & $\mathbf{2 0 0 0}$ & $\mathbf{2 0 1 0}$ & $\mathbf{2 0 2 0}$ & $\mathbf{2 0 3 0}$ & $\mathbf{2 0 4 0}$ & $\mathbf{2 0 5 0}$ \\
\hline Urban population & 11.8 & 16.2 & 17.4 & 19.4 & 26.4 & 35.9 & 49.2 & 61.4 & 70.6 & 76.4 & 80.0 \\
\hline Source: UN, 2018 [6]. & & & & & & & &
\end{tabular}




\subsection{Impacts of Population Policy}

In connection with the current population development in the country, implemented in the spirit of the one-child policy, certain threats arise for China in both the economic and social spheres. The country is beginning to suffer from the problem of an aging population and its consequences for society as a whole. The demographic threat is associated with a rapid increase in the productive and, above all, post-productive population and, on the other hand, as a result of the one-child population policy, with a significant reduction in the pre-productive population.

Society will thus change at an alarming rate towards an aging population. Between 2010 and 2050, in China there will be almost 275 million people over 60 years of age. Their share in the total population will be $31 \%$ in 2050 , while in 2010 it was $12.3 \%$. The share of the population older than 80 years will be more than $7 \%$, while in 2010 this share was only $1.4 \%$ (see Tables 2 and 3). Graphically, the situation is processed in the Figure 1.

Table 2. Development of the Chinese population (million inhabitants—middle variant).

\begin{tabular}{cccccccccc}
\hline Age Group & $\mathbf{1 9 5 0}$ & $\mathbf{1 9 7 0}$ & $\mathbf{1 9 9 0}$ & $\mathbf{2 0 0 0}$ & $\mathbf{2 0 1 0}$ & $\mathbf{2 0 2 0}$ & $\mathbf{2 0 3 0}$ & $\mathbf{2 0 5 0}$ & $\mathbf{2 1 0 0}$ \\
\hline $0-14$ & 188.7 & 334.4 & 336.5 & 319.9 & 255.4 & 254.9 & 230.9 & 198.4 & 146.8 \\
\hline $15-65$ & 341.1 & 462.2 & 774.2 & 882.7 & 1002.9 & 1012.1 & 986.5 & 838.4 & 579.9 \\
\hline $65+$ & 24.6 & 31.0 & 66.3 & 87.9 & 110.5 & 172.3 & 247.0 & 365.6 & 339.2 \\
\hline Total & 554.4 & 827.6 & 1176.9 & 1290.6 & 1368.8 & 1439.3 & 1464.3 & 1402.4 & 1065.0 \\
\hline
\end{tabular}

Source: UN, 2019 [5].

Table 3. Development of the Chinese population (percentage-middle variant).

\begin{tabular}{cccccccccc}
\hline Age Group & $\mathbf{1 9 5 0}$ & $\mathbf{1 9 7 0}$ & $\mathbf{1 9 9 0}$ & $\mathbf{2 0 0 0}$ & $\mathbf{2 0 1 0}$ & $\mathbf{2 0 2 0}$ & $\mathbf{2 0 3 0}$ & $\mathbf{2 0 5 0}$ & $\mathbf{2 1 0 0}$ \\
\hline $0-14$ & 34.0 & 40.4 & 28.6 & 24.8 & 18.7 & 17.7 & 15.8 & 14.2 & 13.8 \\
\hline $15-65$ & 61.6 & 55.8 & 65.8 & 68.4 & 73.2 & 70.3 & 67.3 & 59.7 & 54.3 \\
\hline $65+$ & 4.4 & 3.8 & 5.6 & 6.8 & 8.1 & 12.0 & 16.9 & 26.1 & 31.9 \\
\hline
\end{tabular}

Source: UN, 2019 [5].

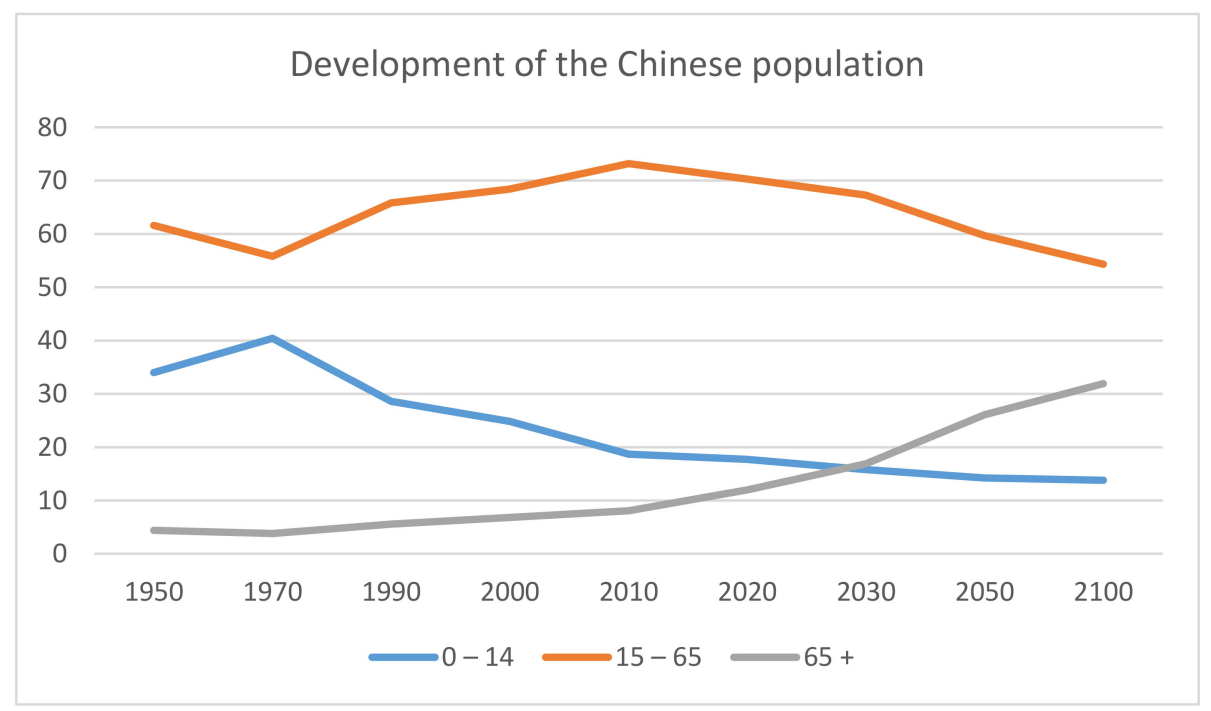

Figure 1. Development of the Chinese population. Source: authors processing according to UN, 2019 [5].

\subsection{Impacts on the Pension and Social System}

For decades, there has been a separate pension system in China for civil servants and other civil servants, such as teachers, who did not have to pay their own pension 
contributions and were entitled to a generous government-subsidized pension upon retirement. However, in January 2015, in its decision on the reform of the state occupational pension scheme, the Council of State introduced a new pension plan aimed at balancing the private and public sector schemes. Under the new system, public sector employees have to contribute to the pension fund themselves. However, the authorities stated that the basic salaries and pension benefits of civil servants and employees of public institutions would be increased accordingly to compensate for any financial losses of employees under the new scheme.

One of the biggest problems with China's current pension system is the legal retirement age: 60 years old for men and 50 years old for women working in companies, and 55 years old for women officials. These limits were set in the 1950s and are clearly no longer realistic in a country where life expectancy has improved significantly over the last few decades and has moved closer to developed countries. There was a 20 -year difference between China and the OECD average in 1960; in 2014, this gap narrowed to less than five years. China's average life expectancy is currently about 76 years [17] and about 12 percent of the population is over 65 years old. The Chinese government has long acknowledged this problem, and officials have announced various plans to gradually raise the legal retirement age in China. For example, in March 2018, Deputy Minister of Human Resources and Social Security Tang Tao said that the government's goal is to increase the retirement age of women by one year every three years, while the retirement age of men will increase by one year every six years, so that retirement age for both men and women is 65 until 2045. However, definitive regulations on raising the retirement age do not yet exist.

China's shrinking workforce and rapidly aging population have raised concerns about the future sustainability of the basic urban pension fund. One major report predicts that total spending will start to exceed contributions in 2028 and that reserves will then decline exponentially, leading to a full depletion of the fund by 2035 .

The number of workers in China contributing to the basic urban pension plan has almost doubled in the last ten years, but still represents only about 69 percent of the total urban workforce. In addition, the proportion of pensioners receiving benefits has increased much faster [7].

By 2050, there will be more retirees in China than people in the United States, and more than 100 million Chinese will be over eighty years old. The working-age population in China will start to decline in 2015. This is a direct consequence of the one-child policy that the country has implemented.

This will have a huge impact on China's competitiveness, not to mention its ability to finance social measures. China is currently the third largest economy in the world and per capita income has increased tenfold since the 1970s, but it is still a developing country. Unlike other aging countries, these changes are taking place in China at a time when its population is still poor-more than 100 million Chinese live on less than one dollar a day. How the government deals with this demographic change will affect the country's future prosperity and stability. What are its options? More and more votes are calling for the abolition of controversial rules on the number of children, which would increase the next generation of taxpayers on whom the economy depends. However, even that is a problem in the short term. The problem, of course, is that the children will not be working for the next few years, so they will be in a much worse situation and the state will have to spend more.

In recent years, the Chinese government has been working to create a new social security system based on individual employment contracts, which would be liable rather than the state for pension contributions, unemployment, health insurance, work-related injuries, and maternity insurance. In addition, the government has set up a housing fund to help civil servants who no longer have housing available to buy their own homes.

The new system has been created gradually through a series of specific regulations and provisions in 1994 labour law and in 2008 labour law, etc. These separate parts were codified in the form of a comprehensive national framework in the Social Insurance Act 
only in 2011. The basic principles of the Chinese social security system set out in the Social Insurance Act are the following:

- $\quad$ all workers, including rural migrant workers, should be insured under a social security scheme;

- $\quad$ both employers and employees are required to pay contributions (at different rates) to the pension fund, the unemployment insurance fund, and the health insurance fund, as well as to the housing provider's fund. Employers, but not employees, are also required to contribute to accident and maternity insurance funds;

- $\quad$ individual insurance funds are managed by local governments and grouped into provincial or municipal funds. Usually it is the local labour, human resources, and social insurance departments that manage social insurance funds, while the housing provider fund is managed by the local government's housing management fund committee;

- $\quad$ the raised funds must be used only for the intended purpose, namely to provide social insurance for workers and pensioners;

- $\quad$ pension and health insurance funds consist of combined components from which benefits can be drawn for each eligible employee and personal accounts for the benefit of the individual employee concerned [7].

Social security benefits should remain for workers even if they move. However, this provision has proved very difficult to implement due to the highly localized nature of the welfare system in China. Acquiring different jurisdictions to share information is fraught with bureaucratic and technical difficulties, especially for workers coming from rural areas of China.

The basic framework for the Chinese pension system was established in 1997 on the basis of a decision of the Council of State to establish a single basic pension system for workers in enterprises. Employees and employers are obliged to pay contributions to the pension system. For decades, there has been a separate pension system in China for civil servants and other civil servants, such as teachers, who did not have to pay their own pension contributions and were entitled to a generous government-subsidized pension upon retirement. However, in January 2015, in its decision on the reform of the state occupational pension scheme, the Council of State introduced a new pension plan aimed at balancing the private and public sector schemes. Under the new system, public sector employees have to contribute to the pension fund themselves.

China's pension system has undergone extensive structural reforms in recent years. At least in urban areas, the current system has three pillars. The public pillar is divided between the rolling scheme and the individually funded accounts. The second pillar consists of voluntary occupational pensions in the form of company pensions, and the third pillar consists of voluntary private savings.

China's public pension system includes urban and rural systems. The rural system has been designed specifically for rural areas and differs significantly from the system in place in urban areas [73]. Participation in pensions is voluntary and operational matters are left to local governments. Compared to the urban pension system, benefits are much less generous, and participation in the rural system is very limited. According to estimates from 2003, it was attended by 54 million people, which represents $9 \%$ of the total rural population. In 2006, a pilot project was launched in rural Beijing to involve more people. Its aim is to include the larger rural population of Beijing, which has more than three million people, in the formal pension system. Following pilot projects in Shanghai and Guangzhou, the urban pension system was officially launched in 1997 with the announcement of a revised pension policy. While pensions were provided by state-owned enterprises in the previous system, the social security system was taken over. The reform was launched at the provincial level with a view to extending it to the national level [74].

This public pension system consists of pillar 1A, a pay-as-you-go portion, and pillar $1 \mathrm{~B}$, a funded portion consisting of individual accounts. Pillar 1A is financed exclusively by employer contributions of $20 \%$ of wages, whereas pillar $1 \mathrm{~B}$ is financed by employee 
contributions of $8 \%$. The pay-as-you-go portion is intended to provide a replacement rate of $35 \%$ of the employee's final salary, and the funded portion aims to replace $24 \%$. Contribution rates were changed in 2006. Until then, pillar 1A was financed by a $17 \%$ employer contribution. Pillar 1B was financed by employee contributions amounting to $3 \%$ of their salaries, and by employers, who made an $8 \%$ contribution. The urban pension system has a coverage rate of $50 \%$ [75].

In the context of the slowdown in economic growth and a rapidly aging population, the Chinese government is aware that it needs to figure out how to take care of its older people. The stakes are extremely high: in a culture that has long placed high bonuses on age and respect for the elderly - and where the state has recently embraced and upheld Confucian ideals and values as a means of promoting social harmony and stability-care for the elderly and social security closely relate to the legitimacy of the state [76].

Chinese pension funds, which in 2017 accounted for almost 70 percent of national social security collections, are crucial to the country's social security infrastructure. However, without generous central government subsidies, Chinese pension funds would get deep into the red and the deficit would increase from 234 billion yuan (about $\$ 35$ billion) to 534 billion yuan by 2022. According to a report by the Chinese Academy of Social Sciences, almost half of China's provinces have reported operational shortcomings in their basic pension funds by 2022, compared with six in 2015. Some provinces are more affected than others. In July 2018, Heilongjiang, a province in the rusty belt of north-eastern China, was forced to delay the payment of pensions because it was unable to meet last year's pension obligations even with state subsidies [7].

A 2018 survey provided by 51 social security information providers in Shebao found that only 27 percent of companies paid the full amount of their social security contributions. Mark Frazier, a professor of politics at the New School and an expert on the Chinese pension system, points out that the highly fragmented nature of the social security system has enabled and perpetuated tax evasion: Social security collections are coordinated at city level, so even in a province the country can be very uneven. Who will collect money from businesses: the local tax office or local ministry of human resources and social security? Officials have difficulty collecting from larger companies because, in many cases, their management has outperformed them, making it relatively easy for businesses to negotiate with local authorities on favourable terms. The complexity of collecting contributions and the high degree of fragmentation also mean that workers and pensioners face reduced retirement benefits-and sometimes none at all.

The shackled system is causing great concern to workers and pensioners who are trying to collect their monthly pensions-especially migrating and temporary workers. The localized system makes it difficult for many migrating workers to register a city pension. In 2017, 62 million migrating workers successfully registered as city workers, which is only about 22 percent of the total number of such Chinese workers. If a migrating worker cannot successfully enrol in his or her city's pension scheme, his or her pension will continue to be paid to their hometown. In the absence of a central process for integrating pension systems between localities, urban and rural pensions differ significantly: retirees in Beijing, Shanghai, and Shenzhen collect around 4000 yuan (\$596) per month, while their counterparts in small villages claim only 90 yuan (\$13) per month. This means that due to the high cost of living, many migrants are forced to go to their hometowns after they have been retired for decades in the cities they helped build.

These issues are more pressing in the context of broader demographic challenges and labor force trends. By 2050, up to a third of China's population will be over 60 years old. Due to declining births, the workforce is shrinking. According to a national survey conducted by the Ministry of Human Resources and Social Security last year, the ratio of workers to pensioners has fallen dramatically. In 2011, each pensioner was supported by 3.1 workers (contributors to the fund). By the end of 2017, this ratio had dropped to 2.8 per one, and the ministry estimates that by 2050 it will be only 1.3 per one. This imbalance will 
widen the pension deficit, causing the provinces to rely even more on central government subsidies.

The current level of government spending on social services and security is also, according to Cai et al. [77], unsustainable. According to a recent study published in the New York Times by sociologists Wang, Shen, and Cai, China's public spending on education, health care, and pensions rose from $6.3 \%$ of GDP in 2007 to $11.6 \%$ of GDP in 2016-faster than spending on military or domestic security programs. This rate is projected to double to 23 percent by 2050, equivalent to the share of GDP in all current government spending.

In an effort to create a more centralized collection system, in July 2018 China approved an ambitious tax reform plan with great emphasis. At the heart of the reform was a structural overhaul of the way social insurance contributions are collected from companies: the consolidation of notoriously fragmented social security. A system and the provision of larger contributions to society are essential to ending the growing shortage of pensions. In effect from January 1, 2019, all local governments transferred responsibility for collecting social security contributions to the tax authorities, which sought to make the system more efficient and made it more difficult for companies to avoid making the necessary contributions. However, according to Caixin report, at least 10 provincial-level regions that have published implementation announcements have not yet begun collecting fees from companies, presumably in an effort to avoid further financial stress for businesses [78].

China planned to subsidize the shortfall in state pensions caused by mitigation measures for state employers in 2019 at a time of economic difficulties. The situation may worsen as the slowdown slows as the aging population pushes on the younger generation. China's aging population is increasing the pressure on the state pension deficit and employers are lagging behind. According to experts, a deeper economic slowdown could burn a larger hole in the pension stove.

"The cumulative balance in the group was about 5 trillion yuan ( $\$ 712$ billion) at the end of 2019, and employers' contributions are expected to fall by 417.4 billion yuan due to mitigation measures", Deputy Finance Minister Yu Weiping said. The government will increase its subsidies so that payments to retirees can be made in full on time.

In 2019, Prime Minister Li Keqiang reduced the employer's contribution rate to 16 percent from 20 percent to meet the challenges as the economy grew at the slowest pace in 20 years. According to Renee McGowan of Mercer, the shortage suggests that the pension system is unsustainable as the aging demographic group deteriorates in the coming decades: "The government must focus on raising the retirement age," despite it being a globally unpopular topic, as "you can't have a half-life pension system."

China's statutory retirement age starts at 50 for women and 60 for men. While the average life expectancy in China is around 77 years, according to UN statistics, McGowan said that many Chinese people have lived for over 100 years. China is aging much faster than other low-and middle-income countries, and the proportion of the population aged 60 and over will increase to 28 percent by 2040 from 12.4 percent in 2010, according to a report by the World Health Organization [79].

China acknowledged this problem at the end of last year (2019) by outlining a fivepoint strategy for managing the aging of the population through a first policy paper issued jointly by the Communist Party's Central Committee and the Council of State. Although it lacks a solution, it plans to solve the dilemma "with Chinese characteristics".

According to one projection published by the World Economic Forum, China's pension deficit could increase to $\$ 119$ trillion by 2050 from $\$ 11$ trillion in 2015. According to Wina Appleton of JPMorgan Asset Management, many Chinese provinces are underfunded in the pension fund despite state subsidies.

China's state-of-the-art pay-as-you-go pension model means that most of the younger generation will be burdened with supporting retirees, said Appleton, Asia-Pacific pension strategist at JPMAM. The current ratio of five working employees supporting each pensioner could deteriorate to two to one by 2050, she added. According to a Credit Suisse 
report published in January 2020 [80], China's population of people aged 65 and over will be ahead of the population aged $10-25$ by 2032 .

It is true that the Chinese regulators have introduced some reforms in recent years. Since 2018, the China Securities Regulatory Commission has begun approving investment funds to support a voluntary individual pension savings scheme. According to Appleton, about 64 funds have been launched by the end of 2019, allowing individuals to save for their retirement needs through private schemes that invest in the stock and bond markets for diversification and higher returns [81].

\subsection{Policy Loosening}

Since 2007, the first signs anticipating loosening of a one-child policy have been released in the media. The main impetus was that the Chinese government allowed, due to the aging population in large cities such as Guangzhou, parents to be granted an exemption to have a second child. Although this exemption could have been obtained before, it was not possible to obtain it in very crowded areas. During this period, $35.9 \%$ of the Chinese population was allowed to have only one child, and $52.8 \%$ could have had a second child if the first was a daughter. Only $9.6 \%$ of the population had a second child, regardless of gender. For $1.6 \%$ of the population, mainly members of national minorities (mostly Tibetans), there were no restrictions [82].

On 21 March 2014, the state news agency Xinhua News Agency issued a press release entitled "Beijing relaxes family planning policy" [83]. According to the report, it was officially announced that the Chinese government plans to allow couples to have a second child. The only condition is that at least one of the partners is born as an only child. The relevant amendment to the law was approved at a meeting of the State Committee of the Beijing Assembly of People's Deputies. The primary goal of this strategy was to support the birth rate in China, thereby seeking to reduce the financial burden of caring for an aging population. The Beijing government was probably based on data on low birth rates in the capital region. It is here that the birth rate has been at the level of one birth per woman for almost 20 years. Birth rates must be maintained at a minimum of 2.1 children per woman if the population is not to shrink. In addition to Beijing, the release was authorized by local authorities in other areas of the People's Republic of China. One-child policy has been abandoned in Tianjin, Zhejiang, Jiangx, and Anhui Province. The provinces of Guangx, Hubei, and Jiangs followed after some time. The remaining provinces were to join in the following period. The Chinese government and the international community anticipated that easing the one-child policy would increase pressure on medical, maternity, and school facilities to increase the quality and level of their services. Experts have calculated that the number of newborns will increase, because approximately two million couples were projected to apply for a second baby in 2014 due to the loosening of the one-child policy [84].

The 2015 report on the Chinese government's activities, which was presented at a meeting of the China National People's Congress [85], stated that the government will take care to reduce the impact of family planning. The unanswered question, however, is not whether official family policy will ease in China, but when it will actually happen. This step is directly dependent on economic development, which is extremely important for the Chinese government. It was assumed that the official abolition of the one-child policy would take place only after the adoption of the new five-year plan, i.e., after 2015.

On 29 October 2015, the Central Committee of the Communist Party abolished the one-child policy, which lasted almost 40 years [86]. However, some contraceptives still remain in China, and the "two children" policy is currently in force [87]. It is generally believed that the birth rate in China will not increase significantly with the end of the one-child policy [88]. In fact, China may even experience a further decline in fertility in the foreseeable future until it sees any increase in birth rates. Such a scenario, if it turns out to be so, indeed follows the "norm" of demographic trends in other East Asian economies, including Japan, Korea, and, to a lesser extent, Thailand and Vietnam. 
In the 1960s, Chinese women had an average of more than six children. However, this number decreased drastically in the early 1970s, before the implementation of the famous one-child policy. At the end of the 1970s, when the one-child policy was adopted, there was a further decline in fertility levels.

The result of this policy is a drastic reduction in the overall birth rate (fertility index), as documented in the following Table 4.

Table 4. Development of overall birth rate (fertility index).

\begin{tabular}{|c|c|c|c|c|c|c|c|c|c|c|c|c|}
\hline & $\begin{array}{l}1965- \\
1970\end{array}$ & $\begin{array}{l}1965- \\
1970\end{array}$ & $\begin{array}{l}1970- \\
1975\end{array}$ & $\begin{array}{l}1975- \\
1980\end{array}$ & $\begin{array}{l}1980- \\
1985\end{array}$ & $\begin{array}{l}1985- \\
1990\end{array}$ & $\begin{array}{l}1990- \\
1995\end{array}$ & $\begin{array}{l}1995- \\
2000\end{array}$ & $\begin{array}{c}2000- \\
2005\end{array}$ & $\begin{array}{c}2005- \\
2010\end{array}$ & $\begin{array}{c}2010- \\
2015\end{array}$ & $\begin{array}{c}2015- \\
2018\end{array}$ \\
\hline $\begin{array}{c}\text { Fertility } \\
\text { index }\end{array}$ & 6.18 & 6.12 & 4.64 & 3.00 & 2.58 & 2.53 & 1.87 & 1.60 & 1.60 & 1.62 & 1.65 & 1.68 \\
\hline
\end{tabular}

Source: The World Bank, 2020 [17].

Since 1993, total fertility has been, according the World Bank [17], below the level of substitution in China. It is worth noting that similar declining trends in fertility have been observed in many neighboring countries in East Asia, and that these declines may persist for a relatively long period of time, such as half a century or even longer. These countries have not pursued a one-child policy; however, their fertility rates also declined as they began to prosper economically.

In 2016, the Chinese parliament officially approved a proposal to abandon the state policy of one child. However, it is questionable whether this change will bring a positive result. The people of China have become accustomed to smaller families. Based on research, many married couples are no longer interested in a second child for career reasons or cannot afford it financially [89].

The threat of a low fertility trap forces us to consider the existence of a fertility cliff in China, specifically the fertility threshold below which all pension systems would be de facto bankrupt. Theoretically, any pension system can be sustainable by adjusting the contribution rate, the amount of benefits, the retirement age, or a combination thereof. However, a pension system should be considered de facto bankrupt if it requires unrealistically high contribution rates or unfortunately low benefits or an excessively high retirement age. As a result, the sustainability of China's pension system can be judged by its ability to prevent de facto bankruptcy, which depends not only on the system's internal parameters, but also on whether such a fertility cliff exists and, if so, where China is now in relation to it.

President $\mathrm{Xi}$ Jinping is partly aware of this negative population development. Despite strong opposition from within the party, he decided to abolish the one-child policy and has since significantly weakened the power and position of the National Office for Family Planning. In 2018, this office ceased to exist. However, according to some authors [85], the president is still influenced by supporters of negative policies, which is also evident from the fact that even in 2019, he did not lift all birth restrictions and did not end the harmful policy of population control for good.

Yi and his colleagues (in the above-mentioned publication Big Country with an Empty Nest) [44] believe that population decline has already begun or will begin in 2021 at the latest. Extreme assumptions estimate that China's population could fall as low as 400 million by 2100, the same value as in 1911, when the Qing Dynasty was overthrown. By then, half the population will be over 65 years old and China will become insignificant on the world stage. With such a declining population, China will find by the middle of the century that it will be impossible to maintain the current large-scale security staff and stability apparatus, not to mention pension and social security spending. The outdated population will also significantly limit China's military capabilities, and it is very unlikely that the country could be a long-term rival for the USA. Demographic developments in China to date may mean that the country's leadership, the Communist Party, will simply 
not be able to reverse the enormous demographic damage it has done to the Chinese nation over the past four decades [90].

\section{Discussion}

Whilst scholars in many disciplines have studied the impacts of the one-child policy extensively, empirical research on the consequences of the policy beyond family formation, for example its impact on children's everyday lives, and the contradictory effects of the onechild policy on family life has been limited. China's one-child policy was a phenomenon specific to a certain historical period, conditioned by Chinese sociocultural contexts, and it has caused, inter alia, gender inequality issues. Moving forward, it is important to consider how the new two-child policy, currently in effect, will intersect with the on-going impacts of its predecessor. In fact, fertility rates have reached very low levels in China. Actually, China may face the problem of a low fertility trap, where the prevailing low fertility level causes a further decline in fertility. With such a threat of a low fertility trap, the Chinese government began to ease birth control in 2013 by allowing couples to have a second child if one of the parents was a single child [18]. However, few have decided to do so; it was estimated that only $7 \%$ of eligible couples applied for permission to have a second child [19]. It is necessary to realize that there is no obvious reason to believe that China, when it enters the so-called low-fertility trap, can easily and timely escape once the government releases birth control. Two years after the abolition of the one-child policy, the birth rate in China in 2018 reached 10.94 per 1000 populations, the lowest level since 1949 [56].

Based on the findings, the authors confirm the fact that demographic processes and results are considered to be the best measures to understand human societies and changes. It is essential to study social phenomena and, using a demographic perspective, to examine the links between social, economic, political, and cultural forces and demographic processes. There is namely a demographic asymmetric impact on the financial health of the pension system, as even a very optimistic fertility assumption cannot significantly improve the future old-age dependency ratio profile, while persistently low fertility levels can lead to very high levels of future old-age dependency and thus create great financial pressure on the pension system. According to Tao and Li [47], China has reacted and discontinued the special pension plan for civil servants and integrated this privileged welfare class into the urban old-age pension insurance program, in the latest reform.

With the introduction of the "Ordinance establishing a unified basic pension insurance system for urban and rural residents" adopted in 2014, the Chinese government has realized the political will of a universal coverage pension arrangement. Through this pension plan, China is trying to merge the two pension schemes in urban and rural areas into a universal one based on a non-contributory social pension and a personal pension heavily subsidized by governments at different administrative levels. Nearly 498 million people were covered by this pension plan by the end of 2013. Through the creation of the universal pension scheme, theoretically, each Chinese citizen is entitled to participate in the pension arrangement [47]. With these steps, China has achieved a degree of universalism and integration of its pension arrangement unprecedented in the non-Western world.

\section{Conclusions}

Currently, the importance of demographic processes for the development of society is growing, which results in their broad-spectrum operation in individual countries. The clear trend that is taking place in economically developed countries is leading to a reduction in natural growth and the consequent aging of the population.

From a demographic point of view, the authors concluded from the analyses that China is currently facing two trends in the context of historical development: First, life expectancy in China has improved significantly over the last few decades and has moved closer to developed countries. Second, China's fertility rate has changed even more dramatically. In view of these serious demographic trends currently facing China, there is no guarantee that 
the intended and implemented changes aimed at ensuring a sustainable and functioning pension system will not ultimately lead to its collapse.

It is essential to realize that though China's pension reforms are ambitious, they are necessary, given that the previous system was completely different but insufficient for the new economic environment. Given the size of the country and regional differences, the introduction of the new system is a major challenge. This is the main reason why the government has focused on developing a formal pension system in urban areas. The rural pension system with very low coverage has not seen far-reaching reforms. The risk of implementing these reforms is certainly great. Incentive plans and tax cuts could provide temporary relief for declining Gross domestic product (GDP) and easing the effects of the US-China trade war. However, given long-term structural and demographic trends, the risk of major reforms of the pension and social security systems may become even greater.

China's shrinking workforce and rapidly aging population have raised concerns about the sustainability of the urban basic pension fund in the future. One major report predicts that total spending will start to exceed contributions in 2028 and that reserves will then decline exponentially, leading to a full depletion of the fund by 2035 .

The current government has failed to fundamentally restructure its social security system over the last two "reform" decades, with the result that various social security funds are under much greater pressure than they should be. Given the rapidly aging population in China, this poses a particular problem for pension and health insurance funds. The government is now accepting the need to raise the retirement age and carry out far-reaching reforms if there are to be sufficient funds in the future to cover all expected pensions and medical expenses.

However, the government is still reluctant or unable to force employers to comply with existing social security obligations. Rather, the government seeks to reduce the social security burden faced by employers and to pass on the pension and other social security burden to individual workers, whether they are formally employed. Instead of escaping the problems of an employee-based system, the government must find a way to meet the competitive interests of labour and capital in creating a realistic and stable social security system, one that cares for workers during ill health and old age, but also helps to create a satisfied and well-paid workforce that can help the development of the domestic economy through greater innovation, productivity, and consumption of goods and services.

The current demographic development and its effects on society clearly indicate that the subsequent development of Chinese society will be largely determined by the nature of demographic development. The demographic development of recent decades clearly points to the fact of the need to restructure the current system of setting up the economy, in the context of the social and pension system. The presented conclusions and findings in the paper not only point to this need, but also point to the fact of different scientific and political approaches to the researched issues.

Author Contributions: Conceptualization: A.Č. and P.Č.; methodology: P.Č.; software: A.Č.; validation: A.Č. and P.Č.; formal analysis: P.C..; investigation: A.Č. and P.Č.; resources: A.C.. and P.Č.; data curation: A.Č. and P.Č.; writing—original draft preparation: P.Č.; writing—review and editing: A.Č. visualization: A.Č.; supervision: A.Č.; project administration: A.Č.; funding acquisition: A.Č.; All authors have read and agreed to the published version of the manuscript.

Funding: This research was funded by Cultural and Educational Grant Agency of the Ministry of Education, Science, Research, and Sport of the Slovak Republic, grant number KEGA 004/UCM$4 / 2018$.

Institutional Review Board Statement: Not applicable.

Informed Consent Statement: Not applicable.

Data Availability Statement: Data sharing is not applicable to this article.

Conflicts of Interest: The authors declare no conflict of interest. 


\section{References}

1. UN. Total Dependency Ratio ((Age 0-14 + Age 65+)/Age 15-64). 2019. Available online: https://population.un.org/wpp/ Download/Standard/Population/ (accessed on 23 March 2020).

2. UN. Percentage of Total Population by Broad Age Group, Both Sexes (per 100 Total Population). 2019. Available online: https:/ / population.un.org/wpp/DataQuery/ (accessed on 27 October 2020).

3. Yuan, X.; Wan, N. Is Retirement Age Delay Effective for Alleviating the Pressure from Population Ageing? Popul. Res. 2006, 30, 47-54.

4. The World Factbook. Available online: https://www.cia.gov/library/publications/resources/the-world-factbook/ (accessed on 27 March 2020).

5. UN, Department of Economic and Social Affairs, Population Division. World Population Prospects 2019, online ed.; UN: New York, NY, USA, 2019.

6. UN, Department of Economic and Social Affairs, Population Division. World Urbanization Prospects: The 2018 Revision, online ed.; UN: New York, NY, USA, 2018.

7. Čajka, P. Demographic Development of Slovakia in the Context of European Demography; Naučnyj Rezul'tat Sociologija i Upravl'enieBelgorod; Belgorodskij Gosudarstvennyj Nacional'nyj Issledovatel'skij Universitet: Belgorod, Russia, 2019; Volume 5, pp. 79-92.

8. Wang, H.; Huang, J.; Sun, S. Assessment of the Financial Sustainability of China's New Rural Pension Plan: Does the Demographic Policy Reform Matter? Sustainability 2019, 11, 5110. [CrossRef]

9. Wang, H.; Huang, J.; Yang, Q. Assessing the Financial Sustainability of the Pension Plan in China: The Role of Fertility Policy Adjustment and Retirement Delay. Sustainability 2019, 11, 883. [CrossRef]

10. Feng, W.; Cai, Y.; Gu, B. Population, Policy, and Politics: How Will History Judge China's One-Child Policy? Popul. Dev. Rev. 2013, 38, 115-129. [CrossRef]

11. Bongaarts, J.; Greenhalgh, S. An Alternative to the One-Child Policy in China. Popul. Dev. Rev. 1985, 11, 585. [CrossRef]

12. Bhargava, A. Climate change, demographic pressures and global sustainability. Econ. Hum. Biol. 2019, 33, 149-154. [CrossRef] [PubMed]

13. Morone, P.; Falcone, P.M.; Tartiu, V.E. Food waste valorisation: Assessing the effectiveness of collaborative research networks through the lenses of a COST action. J. Clean. Prod. 2019, 238, 117868. [CrossRef]

14. Falcone, P.M.; De Rosa, S.P. Use of fuzzy cognitive maps to develop policy strategies for the optimization of municipal waste management: A case study of the land of fires (Italy). Land Use Policy 2020, 96, 104680. [CrossRef]

15. Hradilová, V. Právní aspekty politiky jednoho dítěte v Číně. Práv. Fórum 2009, 7, 297.

16. People's Republic of China. Population and Family Planning Law of the People's Republic of China. Popul. Dev. Rev. 2001, 19, 61-101.

17. The World Bank. Life Expectancy at Birth, Total (Years). 2019. Available online: http://data.worldbank.org/indicator/SP.DYN LE00.IN (accessed on 6 October 2020).

18. Central Committee of the Communist Party. 2013. Available online: http://www.china.org.cn/china/third_plenary_session/20 14-01/15/content_31203056.htm (accessed on 7 October 2020).

19. CCTV America. Chinese Fertility Rate Drops into “Low Fertility Trap". CCTV America, 2015. Available online: http://www. cctv-america.com/2015/01/05/chinese-fertility-rate-drops-into-low-fertility-trap (accessed on 7 October 2020).

20. National People's Congress. Labor Act. 1994. Available online: https://www.jus.uio.no/lm/china.labor.law.1994/doc.html (accessed on 27 October 2020).

21. Song, Z.; Storesletten, K.; Wang, Y.; Zilibotti, F. Sharing High Growth across Generations: Pensions and Demographic Transition in China. Am. Econ. J. Macroecon. 2015, 7, 1-39. [CrossRef]

22. Oxford, C. Coercive Population Control and Asylum in the U.S. Soc. Sci. 2017, 6, 137. [CrossRef]

23. Greenhalgh, S.; Li, J. Engendering reproductive policy and practice in peasant China: For a feminist demography of repro-duction. Signs 1995, 20, 601-641. [CrossRef]

24. China's Social Security System. 2019. Available online: https://clb.org.hk/content/china\%E2\%80\%99s-social-security-system (accessed on 29 October 2020).

25. Wang, X. Analysis on the Financial Sustainability of Pension System in China. Market Demogr. Anal. 2002, 8, 26-29.

26. Greenhalgh, S. Planned births, unplanned persons: "Population" in the making of Chinese modernity. Am. Ethnol. 2003, 30, 196-215. [CrossRef]

27. Jin, G. The Analysis on the Status and Problems of China's Retirement Age and the Necessity of Extending Retirement Age. Soc. Secur. Stud. 2010, 2, 32-38.

28. Liu, W. Does Late Retirement Surely Damage the Retired Interest? An Investigation on the Pension Wealth of Various Re-tirement Ages of Urban Employees. Econ. Rev. 2013, 4, 27-36.

29. Yuan, Z. Discussion of Delay Retirement and Pension Replacement Rate. Popul. Econ. 2013, 1, 101-106.

30. Yuan, L. Can the Gap of Social Pension Fund Problem Be Settled by Postponing Retirement Age? Simulations of Three Post-poning Retirement Age Proposals under 72 Different Conditions. Popul. Econ. 2014, 4, 82-93.

31. Yu, H.; Zeng, Y. Retirement Age, Fertility Policy and the Sustainability of the Basic Pension Fund in China. J. Finance Econ. 2015, $41,46-57$. 
32. Dou, X.; Ramos, B.A.; Cladera, J.R. China's population policies: Past, present and future. ACE Arch. City Environ. 2018, 12, 201-218. [CrossRef]

33. Xu, Y.; Woodyer, T. The SAGE Encyclopedia of Children and Childhood Studies; SAGE Publications Inc.: Thousand Oaks, CA, USA, 2020.

34. Zhu, Y. Recent developments in China's social security reforms. Int. Soc. Secur. Rev. 2002, 55, 39-54. [CrossRef]

35. Dong, K.; Ye, X. Social security system reform in China. China Econ. Rev. 2003, 14, 417-425. [CrossRef]

36. Leung, J.C. Social security reforms in China: Issues and prospects. Int. J. Soc. Welf. 2003, 12, 73-85. [CrossRef]

37. Salditt, F.; Whiteford, P.; Adema, W. Pension Reform in China: Progress and Prospects; OECD Social, Employment and Migration Working Papers, no. 53; OECD: Paris, France, 2007.

38. Williamson, J.B.; Price, M.; Shen, C. Pension policy in China, Singapore, and South Korea: An assessment of the potential value of the notional defined contribution model. J. Aging Stud. 2012, 26, 79-89. [CrossRef]

39. Oksanen, H. China: Pension Reform for an Aging Economy. In Nonfinancial Defined Contribution Pension Schemes in a Changing Pension World; The World Bank: Washington, DC, USA, 2012; pp. 213-258.

40. Bingwen, Z. China: An Innovative Hybrid Pension Design Proposal. In Nonfinancial Defined Contribution Pension Schemes in a Changing Pension World; The World Bank: Washington, DC, USA, 2012; pp. 189-212.

41. $\mathrm{Wu}, \mathrm{L}$. Inequality of Pension Arrangements Among Different Segments of the Labor Force in China. J. Aging Soc. Policy 2013, 25, 181-196. [CrossRef]

42. Dorfman, M.C.; Holzmann, R.; O'Keefe, P.; Wang, D.; Sin, Y.; Hinz, R. China's Pension System-A Vision; The World Bank: Washington, DC, USA, 2013.

43. Wang, L.; Beland, D.; Zhang, S. Pension fairness in China. China Econ. Rev. 2014, 28, 25-36. [CrossRef]

44. Cai, Y.; Cheng, Y.; Claus, I.; Oxley, L. Pension reform in China: Challenges and opportunities. J. Econ. Surv. 2014, 28 , 636-651. [CrossRef]

45. Cheng, Y.; Gao, S.; Li, S.; Zhang, Y.; Rosenberg, M. Understanding the spatial disparities and vulnerability of population aging in China. Asia Pac. Policy Stud. 2019, 6, 73-89. [CrossRef]

46. Furuoka, F. Is population beneficial to economic growth? An empirical study of China. Qual Quant. 2018, 52, 209-225. [CrossRef]

47. Liu, T.; Sun, L. Pension Reform in China. J. Aging Soc. Policy 2015, 28, 15-28. [CrossRef] [PubMed]

48. Zhu, H.; Walker, A. Pension system reform in China: Who gets what pensions? Soc. Policy Adm. 2018, 52, 1410-1424. [CrossRef]

49. Zhao, Y.; Bai, M.; Feng, P.; Zhu, M. Stochastic Assessments of Urban Employees' Pension Plan of China. Sustainability 2018, 10, 1028. [CrossRef]

50. Stauvermann, P.J.; Kumar, R.R. Demographic change, PAYG pensions and child policies. J. Pension Econ. Financ. 2016, 17, 469-487. [CrossRef]

51. Zhao, Q.; Mi, H. Evaluation on the Sustainability of Urban Public Pension System in China. Sustainability 2019, 11, 1418. [CrossRef]

52. McCurry, J.; Kollewe, J. China Overtakes Japan as World's Second-Largest Economy. The Guardian, 2011. Available online: http: / / www.theguardian.com/business/2011/feb/14/china-second-largesteconomy (accessed on 27 October 2020).

53. Bloomberg. China Eclipses U.S. as Biggest Trading Nation. 2013. Available online: http://www.bloomberg.com/news/articles/ 2013-02-09/ china-passes-u-s-to-become-the-world-sbiggest-trading-nation (accessed on 23 October 2020).

54. Jenkins, R.; Peters, E.D.; Moreira, M.M. The Impact of China on Latin America and the Caribbean. World Dev. 2008, 36, 235-253. [CrossRef]

55. Tan, K.Y.; Abeysinghe, T.; Tan, K.G. Shifting Drivers of Growth: Policy Implications for ASEAN-5. Asian Econ. Pap. 2015, 14, 157-173. [CrossRef]

56. National Bureau of Statistics of China. 28 February 2020. Available online: http://www.stats.gov.cn/english/PressRelease/2020 02/t20200228_1728917.html (accessed on 28 February 2020).

57. Yi, F. A Big Country with an Empty Nest; Dafeng Publishing House: Hong Kong, China, 2007.

58. ̌ezanka, M. Populační Vývoj: Čína ve Druhé Polovině 20. Století. Demografie.. 2007. Available online: http:/ /www.demografie. info/?cz_detail_clanku\&artclID=443 (accessed on 27 March 2020).

59. Peng, Y. Should We Have a Second Child? Reproductive Decisions and Family Negotiation under China's Two-child Policy. J. Contemp. China 2020, 29, 792-807. [CrossRef]

60. Ma, Y. A New Theory of Population; Springer International Publishing: Berlin, Germany, 1989; pp. 300-322.

61. Banister, J. Population Policy and Trends in China, 1978-1983. China Q. 1984, 100, 717-741. [CrossRef]

62. Banister, J. Population, Public Health and the Environment in China. China Q. 1998, 156, 986-1015. [CrossRef]

63. Feeney, G.; Feng, W. Parity Progression and Birth Intervals in China: The Influence of Policy in Hastening Fertility Decline. Popul. Dev. Rev. 1993, 19, 61. [CrossRef]

64. Greenhalgh, S. Shifts in China's Population Policy, 1984-1986: Views from the Central, Provincial, and Local Levels. Popul. Dev. Rev. 1986, 12, 491. [CrossRef]

65. Van De Walle, E.; Malthus, T.R.; Appleman, P. An Essay on the Principle of Population: Text Sources and Background Criticism. Contemp. Sociol. A J. Rev. 1977, 6, 340. [CrossRef]

66. China: Law of 1992 on the Protection of Women's Rights and Interests. 3 April 1992. Available online: https://www.refworld org/docid/4a38f8b72.html (accessed on 13 February 2021).

67. The New Chinese Law on Maternal and Infant Health Care. Popul. Dev. Rev. 1995, 21, 698. [CrossRef] 
68. Collection of the Laws of the People's Republic of China (Supplemented 1990-1992); Ji Lin People's Press: Changchun, China, 1991; pp. 30-33. Available online: https://www.ilo.org/dyn/natlex/natlex4.detail?p_isn=37868\&p_lang= (accessed on 6 October 2020).

69. Thomas, E. China's One-Child Policy: The Party's Rationale and the People's Response; Student Theses, Papers and Projects (History), Western Oregon University: Monmouth, OR, USA, 2011. Available online: https://www.wou.edu/las/socsci/history/senior_ seminar_papers/2011/ (accessed on 23 October 2020).

70. Brenčič, M. Deti len na povolenie. Domino fórum. 2001, 10, 12.

71. ČTK, Focus, HN. Mužská Subkultúra v Číne. Hospodárske Noviny, 11 August 2005. Available online: https://hnonline.sk/svet/17 3543-muzska-subkultura-v-cine (accessed on 27 October 2020).

72. Procházková, K. Na Juhu Číny Utajují Nepokoje Vzniklé Kvůli Politice Jednoho Dítěte. Britské Listy. 2007. Available online: https:/ / legacy.blisty.cz/art/34597.html (accessed on 6 October 2020).

73. Ademola, F.; Oke, F.; Nwani, V.; Ogbobine, J.; Daramola, D.; Osadiaye, U. Situating Nigeria in the Global Pension Industry; BGL Group: Peterborough, UK, 2010. [CrossRef]

74. Duckett, J. Neoliberalism, Authoritarian Politics and Social Policy in China. Dev. Chang. 2019, 51, 523-539. [CrossRef]

75. Pension System in China. Pension Funds Online. 2015. Available online: https://www.pensionfundsonline.co.uk/content/ country-profiles/china/105 (accessed on 27 October 2020).

76. Chen, T.; Turner, J.A. Fragmentation in Social Security Old-Age Benefit Provision in China. J. Aging Soc. Policy 2015, 27, 107-122. [CrossRef]

77. Cai, Y.; Feng, W.; Shen, K. Fiscal Implications of Population Aging and Social Sector Expenditure in China. Popul. Dev. Rev. 2018, 44, 811-831. [CrossRef]

78. Siwei, C.; Jinbing, L.; Jiefei, L. Local Social Insurance Reform Delayed to Give Businesses a Break. Caixin, 11 January 2019. Available online: https:/ / www.caixinglobal.com/2019-01-11/local-social-insurance-reform-delayed-to-give-businesses-a-break101369186.html (accessed on 7 October 2020).

79. PAHO. Available online: https:/ / www.paho.org/salud-en-las-americas-2017/?p=1864 (accessed on 27 October 2020).

80. The Global Wealth Report 2020. Available online: https://www.credit-suisse.com/media/assets/corporate/docs/about-us/ research/publications/global-wealth-report-2020-en.pdf (accessed on 27 October 2020).

81. Lee, G.; Moon, L.; Ren, D. China's State Pension Plan Needs Retooling as SLOWDOWN, Ageing Population Hit Retirement Pot. South China Morning Post. 24 February 2020. Available online: https://www.scmp.com/business/money/wealth/article/305197 5/chinas-state-pension-plan-needs-retooling-slowdown-ageing (accessed on 7 March 2020).

82. Hu, J. Report to the Seventeenth National Congress of the Communist Party of China on Oct. 2007. Available online: http: //www.china.org.cn/english/congress/229611.htm (accessed on 27 October 2020).

83. Relaxation of Family Planning Policy. Available online: http://www.bjreview.com.cn/Cover_Stories_Series_2014/relaxation_of_ family_planning_policy.html (accessed on 27 October 2020).

84. Burkitt, L. China's Changed One-Child Policy Doesn't Give Baby Boost. The Wall Street Journal. 2014. Available online: https:/ / www.wsj.com/articles/chinas-changed-one-child-policy-doesnt-give-baby-boost-1415359577 (accessed on 29 October 2020).

85. The Guardian. China's Economy Grows at its Slowest Annual Rate for 24 years. 2015. Available online: https: / / www.theguardian. com/world/2015/jan/20/chinas-economy-grows-at-its-slowest-annual-rate-for-24-years (accessed on 7 March 2020).

86. Central Committee of the Communist Party. 2015. Available online: https://chinacopyrightandmedia.wordpress.com/2015/10/ 29/communique-of-the-fifth-plenary-meeting-of-the-18th-central-committee-of-the-chinese-communist-party/ (accessed on 7 March 2020).

87. National People's Congress. 2015. Available online: http://www.gov.cn/xinwen/2015-12/28/content_5028414.htm (accessed on 27 October 2020).

88. Schiermeier, Q. China's birth rate won't be dramatically affected by end of one-child policy. Nature 2015. [CrossRef]

89. Xinhua. 2015. Available online: http://news.xinhuanet.com/english/2015-10/29/c_134763645.htm (accessed on 23 October 2020).

90. Huang, W. Why Communist China's Rise Will be Short-Lived, and its Fate is Already Sealed. 8 October 2019. Available online: https:/ / mercatornet.com/why-communist-chinas-rise-will-be-short-lived-and-its-fate-is-already-seale/24790/) (accessed on 26 October 2020). 